\title{
Afdrif barna á Íslandi sem eru ættleidd erlendis frá
}

\author{
Málfríður Lorange' ${ }^{1}$ sálfræðingur, Kristín Kristmundsdóttir ${ }^{1}$ félagsráđgjafi, Guơmundur Skarphéðinsson¹ sálfræðingur, Björg Sigríður \\ Hermannsdóttir² sálfræðinemi, Linda Björk Oddsdóttir² sálfræðinemi, Dagbjörg B. Sigurðardóttir læknir
}

\section{ÁGRIP}

Inngangur: Undanfarin ár hafa allmörg börn verið ættleidd til İslands. Markmið rannsóknarinnar var að kanna hvaða áhættupættir geta haft áhrif á andlega líðan og hegðun barna ættleiddra erlendis frá.

Efniviður og aðferðir: Upplýsingum var safnað um áhættupætti fyrir ættleiðingu, andlega líðan og hegðunarvanda hjá börnum ættleiddum erlendis frá. Notaður var yfirgripsmikill spurningalisti um petta efni sem var próaður af Dana Johnson, lækni hjá Háskólanum í Minnesóta í Bandaríkunum. Einnig voru lagðir fyrir eftirfarandi staðlaðir hegðunarmatslistar: Spurningalisti um atferli barna (CBCL), Spurningalisti um styrk og vanda (SDQ), Ofvirknikvarðinn (ADHD-RS-IV) og Einhverfumatslistinn (ASSQ). Listarnir hafa áđur verið staðlaððir við almennt pýði.

Niðurstöður: Börn ættleidd eftir 18 mánaða aldur og pau sem hafa dvalið á stofnun lengur en fyrstu 18 mánuði lífsins eru i aukinni áhættu á að sýna einkenni athyglisbrests með ofvirkni og hegðunar- og tilfinningavanda en almennt pekkist. Auk pess skora pau börn sem talin eru hafa sætt alvarlegri tilfinningalegri vanrækslu marktækt hærra á hegðunar og tilfinningamatslistunum en pekkist í almennu pýdi. Tilhneiging í pá veru sást einnig á skori á einhverfumatslistanum. Pau börn sem voru ættleidd fyrir 12 mánaða aldur skoruðu sambærilega við almennt pýði á öllum matslistum.

Ályktun: Niðurstöđurnar benda til pess að börnum sem eru ættleidd eftir 18 mánaða aldur sé hættara við tilfinninga- og hegðunarvanda samanborið við almennt pýði. Niðurstöðurnar styðja að leggja beri áherslu á að börn sem eru ættleidd erlendis frá til Íslands komist sem fyrst til kjörforeldra sinna og dveljist sem styst á stofnun.
'Barna- og unglingageðdeild Landspítala, ${ }^{2}$ sálfræðideild Háskóla Íslands.

Fyrirspurnir: Dagbjörg B. Sigurðardóttir

Barst: 5. júlí 2011 sampykkt til birtingar: 5. desember 2011.

Höfundar tiltaka engin hagsmunatengsl.

\section{Inngangur}

Síðustu prjá áratugi hafa á annan tug barna verið ættleidd til landsins á ári hverju. Mörg peirra hafa dvalið á stofnun fyrir komu, sum jafnvel allt frá fæðingu. Lítið er vitað um hvernig börnunum farnast tilfinningalega eftir komuna til Íslands. Erlendar rannsóknir hafa gefið til kynna að ættleidd börn sem eru fædd utan ættleiðingarlands geti sýnt proskafrávik, auk pess að stríða við hegðunar- og tilfinningalega erfiðleika í meira mæli en önnur börn. Möguleiki barnanna til eðlilegrar tengslamyndunar getur verið skertur eða jafnvel ekki til staðar. ${ }^{1-4}$ Vissir áhættupættir, til að mynda vannæring, áfengisneysla móður á meðgöngu og langvinn stofnanavist geta aukið líkur á skertum proska og vexti, sem og erfiðleikum við myndun geðtengsla og ofvirkni- og einhverfulíkum einkennum. ${ }^{1-4}$ Auk pess geta námserfiðleikar og skert félagsfærni sést hjá pessum börnum. ${ }^{2-7}$

Aðbúnaður á stofnunum sem sinna munaðarlausum börnum getur verið ábótavant og bitnað á líkamlegri og andlegri umhirðu peirra. Gjarnan er um marga umönnunaraðila að ræða og mörg börn á hvern starfsmann., ${ }^{4,7}$ Ef áhættupættir hegðunar- og tilfinningalegra erfiðleika eru greindir snemma er mögulegt að virk íhlutun geti dregið úr síðkomnum afleiðingum.

Markmið rannsóknarinnar var að kanna tengsl áhættupátta fyrir ættleiðingu og ákveðinna geðrænna erfiðleika, metið með stöðluðum kvörðum hjá börnum sem hafa verið ættleidd erlendis frá.

\section{Efniviður og aðferðir}

Rannsóknin er hönnuð eftir fyrirmynd og í samráði við Dana Johnson og samverkamenn hans við University of Minnesota. ${ }^{8}$ Peir hafa gert umfangsmiklar kannanir á heilsu og líðan barna ættleiddra erlendis frá. Að auki hafa peir skoðað viðhorf foreldra peirra og pörf á pjónustu sem börnin og fjölskyldur peirra purfa á að halda.

Pau börn, ættleidd erlendis frá, sem tóku pátt í rannsókninni voru fundin með aðstoð Íslenskrar ættleiðingar, sem eru samtök sem hafa staðið fyrir ættleiðingum erlendra barna hingað til lands. Íslensk ættleiðing aðstoðaði við útsendingu spurningalistanna sem voru notaðir við rannsóknina. Spurningalistarnir voru auðkenndir með númeri fyrir hvert barn, pannig að nöfn og rekjanlegar upplýsingar um pátttakendur voru ekki aðgengilegar fyrir rannsakendur. Í úrtakinu voru foreldrar 276 barna á aldrinum eins til 18 ára. Svör bárust frá foreldrum 130 barna, og svarhlutfall var pví $47 \%$.

Eftirfarandi spurningalistar voru notaðir: Spurningalisti úr rannsókn Dana Johnson, Spurningalisti um styrk og vanda, Ofvirknikvarðinn, Skimunarlisti einhverfurófs og Spurningalisti um atferli barna og unglinga.

Listi Dana Johnson og félaga, sem vinna við alpjóðlega ættleiðingarverkefnið (International Adoption Project), var pýddur og staðfærður að fengnu leyfi. Listinn skiptist í 8 hluta sem beinast að mismunandi páttum í lífi æettleiddra barna. Í listanum er spurt um 
Tafla I. Niðurstöður spurningalista eftir ættleiðingaraldri.

\begin{tabular}{|c|c|c|c|c|}
\hline & $\begin{array}{l}\text { Aldur við } \\
\text { ættleiðingu }\end{array}$ & M & (Sf) & $\mathbf{n}$ \\
\hline \multirow[t]{4}{*}{ Spurningalisti um atferli } & 0-6 mánaða & 19,4 & $(17,0)$ & 26 \\
\hline & 7-12 mánaða & 20,8 & $(18,3)$ & 19 \\
\hline & 13-18 mánaða & 39,5 & $(46,4)$ & 3 \\
\hline & 19-44 mánaða & 45,8 & $(25,1)$ & 8 \\
\hline \multirow{4}{*}{$\begin{array}{l}\text { Spurningalisti um styrk og } \\
\text { vanda }\end{array}$} & 0-6 mánaða & 5,9 & $(4,2)$ & 27 \\
\hline & 7-12 mánaða & 5,8 & $(4,4)$ & 49 \\
\hline & 13-18 mánaða & 6,6 & $(4,7)$ & 35 \\
\hline & 19-44 mánaða & 10,1 & $(5,9)$ & 13 \\
\hline \multirow[t]{4}{*}{ Ofvirknikvarðinn } & 0-6 mánaða & 6,5 & $(7,3)$ & 27 \\
\hline & 7-12 mánaða & 8,8 & $(9,4)$ & 37 \\
\hline & 13-18 mánaða & 8,7 & $(9,1)$ & 16 \\
\hline & 19-44 mánaða & 22,5 & $(14,6)$ & 9 \\
\hline \multirow[t]{4}{*}{ Skimunarlisti einhverfurófs } & 0-6 mánaða & 3,5 & $(4,3)$ & 25 \\
\hline & 7-12 mánaða & 4,2 & $(7,9)$ & 17 \\
\hline & 13-18 mánaða & 12,0 & $(14,1)$ & 3 \\
\hline & 19-44 mánaða & 9,0 & $(5,7)$ & 8 \\
\hline
\end{tabular}

$M(S f)=$ meðaltal (staðalfrávik), N=fjöldi

forsögu ættleiðingar, sögu barns frá ættleiðingu, heilsufar eftir ættleiðingu, vöxt og proska, skólagöngu, atburði í lífi barns, tómstundir og afpreyingu, og í lokin eru spurningar tengdar aðstandendum. Listinn innheldur alls 166 spurningar. Í pessum hluta rannsóknarinnar var unnið úr peim upplýsingum sem varða forsögu ættleiðingar og hegðunar- og tilfinningavanda.

Spurningalisti um styrk og vanda (Strengths and Difficulties Questionnaire, $S D Q$ ) var próaður árið 1997 til að meta styrk og vanda barna á aldrinum fjögurra til 16 ára. ${ }^{9}$ Listinn inniheldur 25 spurningar. Tuttugu spurningar fjalla um mögulega erfiðleika barnsins sem skiptast í fjögur svið: hegðunarvanda, athyglisbrest og ofvirkni/hvatvísi, tilfinningavanda og samskiptavanda. Pessi fjögur svið mynda heildarerfiðleikatölu. Fimm atriði kvarðans meta síðan jákvæða félagshegðun sem er styrkleikasvið barns. Svörin eru á priggja punkta stiku, frá 0 (á ekki við) til 2 (á mjög vel við). Rannsóknir á íslenskri útgáfu kvarðans sýna sambærilega próffræðilega eiginleika og frumútgáfan..$^{10,11}$

Ofvirknikvarðinn (Attention Deficit/Hyperactivity Disorder Rating Scale-IV, ADHD-RS-IV) metur einkenni athyglisbrests með ofvirkni og hefur íslensk pýðing á honum verið í notkun hérlendis.2-14 Á listanum eru 18 atriði og tilheyra 9 peirra flokki einkenna fyrir athyglisbrest og önnur 9 flokki einkenna fyrir ofvirkni/hvatvísi. Spurningum er svarað á fjögurra punkta stiku. Fyrir hvert atriði eru gefnir fjórir möguleikar, frá 0 (aldrei eða sjaldan) til 3 (mjög oft), og er heildarfjöldi stiga pví á bilinu 0-54. Niðurstöður rannsókna á íslenskri útgáfu benda til sambærilegra próffræðilegra eiginleika og frumútgáfa kvarðans..$^{15}$

Skimunarlisti einhverfurófs (Autism Spectrum Screening Questionnaire, $A S S Q$ ) skimar eftir einkennum á einhverfurófi hjá börnum á skólaaldri. ${ }^{16}$ Listinn inniheldur 27 atriði á priggja punkta stiku, frá 0 (á ekki við) til 2 (á mjög vel við), og er pví hægt að fá stig á bilinu 0-54. Próffræðilegir eiginleikar íslenskrar útgáfu kvarðans hafa sömuleiðis reynst sambærilegir frumútgáfu. ${ }^{17}$ Ellefu atriði á listanum snúa að félagslegum samskiptum, 6 mæla tjáskipti og 5 atriði beinast að hamlandi og endurtekinni hegðun. Önnur 5 atriði mæla sérkennilegar hreyfingar og fleiri tengd einkenni.

Spurningalisti um atferli barna og unglinga (Child Behavior Checklist, $C B C L)$ er ætlaður foreldrum til pess að meta hegðunarog tilfinningavandkvæði hjá börnum og unglingum á aldrinum fjögurra til 18 ára. ${ }^{18,19}$ Listinn metur tvo pætti, tilfinningaerfiðleika og hegðunarerfiðleika. Mögulegt er að reikna út heildarvanda. Listinn inniheldur 120 atriði, kom fyrst út 1983 og er einn af mest notuðu listunum til að meta hegðun og líðan barna. Sýnt hefur verið fram á áreiðanleika par sem tengsl eru á milli niðurstaðna á listanum og algengra geðraskana meðal barna og unglinga., 20

SPSS-reikniforrit var notað við úrvinnslu gagna. Hrátölur úr matskvörðunum voru reiknaðar yfir í T-gildi. Íslensk viðmið eru til fyrir ofvirknikvarðann og kvarðann um styrk og vanda og voru pau notuð. ${ }^{11,14}$ Fyrir kvarðann um atferli barna voru notuð bandarísk viðmið. ${ }^{18,}{ }^{19}$ Viðmið úr almennu norsku pýði voru notuð fyrir skimunarlista einhverfurófs. ${ }^{16}$

Tengsl áhættupáttanna (óháðar breytur) aldur við ættleiðingu, lengd stofnanadvalar fyrir ættleiðingu og tilfinningaleg vanræksla og heildarskor á matslistunum (háðar breytur) voru skoðuð með dreifigreiningu (analysis of variance). Aldri við ættleiðingu og lengd stofnanadvalar var skipt í fjóra flokka, 0-6 mánaða aldur, 6-12 mánaða, 12-18 mánaða og svo 18 mánaða og eldri. Mat á tilfinningalegri vanrækslu fyrir ættleiðingu var flokkað í a) engin/ lítil, b) einhver pekkt og c) alvarleg vanræksla. Par að auki voru heildarskor á matskvörðunum fyrir hvern flokk innan hverrar óháðrar breytu borin saman með eftirá prófun til að rannsaka marktækni milli flokka. Niðurstöður eru settar fram sem \pm staðalfrávik pegar við á.

Persónuvernd og Vísindasiðanefnd veittu leyfi til pessarar rannsóknar.

\section{Niðurstöður}

Flest börnin, eða 61 (49,6\%), komu frá Indlandi og 50 (40,7\%) frá Kína. Mikill minnihluti barnanna kom frá Evrópu, eða 7 börn (5,7\%). Prjú komu frá öðrum Asíulöndum (2,4\%) og tvö (1,6\%) frá S-Ameríku. Töluverð aldursdreifing var á börnunum við komu, par sem yngsta barnið var aðeins mánaðargamalt en elsta barnið var 10 ára. Aldursdreifing barnanna var pannig að 27 börn (21\%) voru undir 6 mánaða, 49 börn (38\%) voru 6-12 mánaða, 40 (31\%) voru 12-18 mánaða, 7 (5\%) voru 18-24 mánaða og 6 (5\%) voru eldri en 24 mánaða. Hjá einu barni var aldur ópekktur við ættleiðingu. Meðalaldur við ættleiðingu var 12,4 $( \pm 2,6)$ mánuðir. Meðalaldur barnanna pegar rannsóknin var gerð var 81,9 $( \pm 56,8)$ mánuðir eða 6,8 ár. Langflest barnanna höfðu dvalið á stofnun fyrir ættleiðingu eða $94,2 \%$ (114) en 5,8\% (7) barnanna ekki.

Pegar foreldrar barnanna svöruðu spurningunni hvort pau teldu börnin hafa orðið fyrir andlegri vanrækslu fyrir ættleiðingu, töldu 63 (52,9\%) peirra að börnin hefðu orðið fyrir lítilli/engri andlegri vanrækslu. Foreldrar 38 (31,9\%) barna töldu pau hafa orðið fyrir vægri andlegri vanrækslu en hjá 18 (15,1\%) töldu foreldrar að pau hefðu orðið fyrir alvarlegri andlegri vanrækslu. 
Tafla II. Niðurstöður spurningalista eftir lengd stofnanadvalar.

\begin{tabular}{|c|c|c|c|c|}
\hline & Dvöl á stofnun & $\mathbf{M}$ & (Sf) & $\mathbf{n}$ \\
\hline \multirow[t]{4}{*}{ Spurningalisti um atferli } & 0-6 mánaða & 18,3 & $(17,4)$ & 26 \\
\hline & 7-12 mánaða & 22,2 & $(16,3)$ & 14 \\
\hline & 13-18 mánaða & 50,9 & $(35,5)$ & 3 \\
\hline & 19-44 mánaða & 49,0 & $(32,9)$ & 4 \\
\hline \multirow{4}{*}{$\begin{array}{l}\text { Spurningalisti um styrk og } \\
\text { vanda }\end{array}$} & 0-6 mánaða & 5,7 & $(4,2)$ & 28 \\
\hline & 7-12 mánaða & 6,2 & $(4,1)$ & 36 \\
\hline & 13-18 mánaða & 7,3 & $(4,6)$ & 27 \\
\hline & 19-44 mánaða & 13,6 & $(8,0)$ & 5 \\
\hline \multirow[t]{4}{*}{ Ofvirknikvarðinn } & 0-6 mánaða & 6,1 & $(5,8)$ & 26 \\
\hline & 7-12 mánaða & 8,7 & $(8,2)$ & 30 \\
\hline & 13-18 mánaða & 11,1 & $(9,4)$ & 12 \\
\hline & 19-44 mánaða & 28,2 & $(17,4)$ & 5 \\
\hline \multirow[t]{4}{*}{ Skimunarlisti einhverfurófs } & 0-6 mánaða & 2,8 & $(4,2)$ & 25 \\
\hline & 7-12 mánaða & 3,1 & $(4,9)$ & 13 \\
\hline & 13-18 mánaða & 14,3 & $(11,8)$ & 3 \\
\hline & 19-44 mánaða & 10,2 & $(7,4)$ & 4 \\
\hline
\end{tabular}

$M(S f)$ = meðaltal (staðalfrávik), $N=f j o ̈ l d i$

Tengsl aldurs við ættleiðingu og heildarstiga á spurningalistum var athugað með fylgnistuðli Pearsons. Aldur við ættleiðingu reyndist hafa marktæk tengsl við alla spurningalistana. Fylgni aldurs við ættleiðingu við heildarvandaskor Spurningalista um atferli var $0,31(p<0,05)$ og við heildarvandaskor Spurningalisti um styrk og vanda var $0,28(p<0,01)$. Fylgni við heildarskor Ofvirknikvarðans var $0,45(p<0,001)$ og fylgni við heildarskor Skimunarlista einhverfurófs var $0,27(\mathrm{p}<0,05)$.

Einnig voru tengsl aldurs við ættleiðingu og heildarskors á spurningalistum könnuð með pví að skipta breytunni í fjóra flokka (0-6 mánaða, 7-12 mánaða, 13-18 mánaða og 219) og peir bornir saman eftir heildartölum á spurningalistum. Í ljós kom marktækur munur eftir aldri á Spurningalista um atferli $\mathrm{F}(3,52)=4,137(\mathrm{p}<0,01)$, Spurningalista um styrk og vanda $F(3,120)=3,160(p<0,05)$, Ofvirknikvarðanum $\mathrm{F}(3,858)=5,595$ ( $\mathrm{p}<0,01$, ) en ekki var marktækur munur á Skimunarlista einhverfurófs $\mathrm{F}(3,492)=2,960(\mathrm{p}>0,05)$.

Gerður var samanburður eftir á til pess að kanna nánar mun eftir aldurshópum (tafla I). Enginn munur kom fram á hópunum á Spurningalista um atferli. Á Spurningalista um styrk og vanda kom í ljós að börn ættleidd á aldrinum 19-44 mánaða skoruðu hærra en börn sem ættleidd voru 0-12 mánaða $(10,1 \mathrm{SF}=5,90$ vs 5,9 SF=4,3). Á Ofvirknikvarðanum skoruðu börn ættleidd eftir 18 mánaða aldur marktækt hærra en pau börn sem voru yngri við ættleiðingu (22,5 SF=9,1 vs 6,5-8,8 SF=7,3-9,1). Niðurstöður fyrir Skimunarlista einhverfurófs voru ekki marktækar.

Alls höfðu 114 börn dvalið á stofnun í einhvern tíma en aðeins sjö peirra ekki (tafla II). Aðeins reyndist unnt að bera saman heildartölur Spurningalista um styrk og vanda par sem foreldrar barna sem ekki höfðu dvalist á stofnun svöruðu ekki öðrum spurningalistum. Munur milli hópanna var ekki marktækur t (113)=1,218 $(p>0,05)$. Spurt var hversu lengi börnin hefðu dvalið á stofnun fyrir ættleiðingu. Athuguð voru tengslin við svör á spurningalistum og kom í ljós að allar fylgnitölur voru marktækar. Fylgni lengdar
Tafla III. Niðurstöður spurningalista eftir alvarleika tilfinningalegrar vanrækslu.

\begin{tabular}{lcccc} 
& Vanræksla & M & (Sf) & $\mathbf{n}$ \\
Spurningalista um atferli & engin/lítil & 45,5 & $(8,0)$ & 24 \\
\hline & einhver pekkt & 51,8 & $(11,4)$ & 17 \\
\hline $\begin{array}{l}\text { Spurningalisti um styrk og } \\
\text { vanda }\end{array}$ & alvarleg & 60,7 & $(16,8)$ & 11 \\
\hline & engin/lítil & 47,0 & $(6,6)$ & 61 \\
\hline & einhver pekkt & 53,6 & $(9,9)$ & 35 \\
\hline Ofvirknikvarði & alvarleg & 59,3 & $(11,9)$ & 17 \\
\hline & engin/lítil & 46,4 & $(7,7)$ & 40 \\
\hline & einhver pekkt & 56,2 & $(14,0)$ & 27 \\
\hline Skimunarlisti einhverfurófs & alvarleg & 58,1 & $(15,2)$ & 14 \\
\hline & engin/lítil & 46,5 & $(6,2)$ & 22 \\
\hline & einhver pekkt & 56,4 & $(16,3)$ & 17 \\
\hline
\end{tabular}

$M(S f)$ = meðaltal (staðalfrávik), $N=f j o ̈ l d i$

stofnanavistar við heildarvandaskor Spurningalista um atferli reyndist $0,47(p<0,001)$. Fylgni við heildarvandaskor listans Spurningar um styrk og vanda var $0,36(p<0,001)$. Fylgni við heildarskor Ofvirknikvarðans var 0,49 ( $\mathrm{p}<0,001)$ og við heildarskor Skimunarlista einhverfurófs var fylgni $0,46(\mathrm{p}<0,001)$.

Lengd stofnanavistar var einnig flokkuð í fernt, (0-6 mánuðir, 7-12 mánuðir, 13-18 mánuðir og yfir 18 mánuðir) og heildartölur á spurningalistum bornar saman (tafla II). Marktækur munur kom fram á heildarvandaskori Spurningalista um atferli $\mathrm{F}(3,46)=4,728$ p<0,01. Í ljós kom að börn sem höfðu dvalið 19 mánuði eða lengur á stofnun skoruðu hærra $(49,0 \pm 32,9)$ en pau sem höfðu aðeins dvalið par 0-6 mánuði $(18,3 \pm 17,5)$. Einnig var marktækur munur á heildarvandaskori Spurningalista um styrk og vanda F $(3,95)=4,483$ $\mathrm{p}<0,01$ og par reyndust börn sem höfðu dvalist á stofnun 19 mánuði eða lengur skora hærra $(13,6 \pm 8,1)$ en pau sem höfðu einungis dvalist par í 0-6 mánuði $(5,8 \pm 4,3), 7-12$ mánuði $(6,2 \pm 4,2)$ eða 1318 mánuði $(7,3 \pm 4,7)$. Á heildarskori Ofvirknikvarðans var einnig marktækur munur F $(3,72)=9,579 \mathrm{p}<0,001$. Samanburður milli hópa var pó ekki marktækur með fylgniprófi. Loks var marktækur munur á heildarskori Skimunarlista einhverfurófs $\mathrm{F}(3,44)=5,989$ $\mathrm{p}<0,01$ en enginn samanburður milli hópa var pó marktækur.

Foreldrar voru spurðir hvort peir teldu börnin hafa orðið fyrir tilfinningalegri vanrækslu fyrir ættleiðingu, og voru möguleikarnir: a) engin/lítil vanræksla, b) einhver pekkt vanræksla og c) alvarleg vanræksla (tafla III). Niðurstöður sýndu marktækan mun milli tilfinningalegrar vanrækslu og heildarvandaskora á Spurningalista um atferli $\mathrm{F}(2,49)=6,864(\mathrm{p}<0,01)$ og heildarvandaskora á Spurningalista um styrk og vanda $F(2,110)=15,732(p<0,001)$. Einnig sýndu niðurstöður marktækan mun á heildarskori Ofvirknikvarða $\mathrm{F}(2,78)=8,419$ ( $\mathrm{p}<0,001)$ og Skimunarlista einhverfurófs $F(2,47)=6,990(p<0,01)$. Frekari samanburður var gerður til að sýna hvar munurinn væri til staðar og sýndi Levenes-prófun að dreifing í hópnum var ójöfn. Í framhaldi af pví var Tamhanegreining framkvæmd. Niðurstöður úr Spurningalista um atferli sýndu að pau börn sem talið var að hefðu orðið fyrir alvarlegri vanrækslu skoruðu hærra en börnin sem talin voru hafa sætt lítilli eða vægri vanrækslu. Á Spurningalista um styrk og vanda komu 
pessar sömu niðurstöður í ljós. Niðurstöður Ofvirknikvarða og Skimunarlista einhverfurófs sýndu einnig að pau börn sem voru alvarlega vanrækt skoruðu hærra en börnin sem höfðu orðið fyrir lítilli eða engri tilfinningalegri vanrækslu.

\section{Umræða}

Niðurstöður okkar sýna að erlend börn sem eru ættleidd eftir 18 mánaða aldur og/eða hafa dvalið á stofnun á fyrstu árum ævinnar geta verið í aukinni áhættu hvað varðar tilfinninga- og hegðunarvanda síðar meir. Rannsóknir sýna að börn sem eru ættleidd eftir 18 mánaða aldur og/eða hafa verið vistuð á stofnun í meira en 18 mánuði skora hærra á kvörðum til mats á einkennum athyglisbrests með ofvirkni (ADHD) auk hegðunar- og tilfinningavanda í samanburði við almennt pýði. Að auki eru pau börn sem kjörforeldrar telja að hafi orðið fyrir alvarlegri tilfinningalegri vanrækslu í frumbernsku með marktækt hærra skor á skimunarlistum fyrir hegðunar- og tilfinningavanda. Pó svo að ekki hafi komið fram marktækur munur á einkennum á einhverfurófi við breyturnar aldur við ættleiðingu, lengd stofnanadvalar og tilfinningaleg vanræksla, sást eigi að síður viss tilhneiging í pá veru.

Pau börn sem voru ættleidd fyrir 12 mánaða aldur voru með heildarskor innan eðlilegra marka á öllum matskvörðunum. Раð er í samræmi við niðurstöður erlendra rannsókna, en sú takmörkun var pó á niðurstöðum er varða aldursbilið 12-18 mánaða að einungis foreldrar priggja einstaklinga sem voru á pessu aldursbili við ættleiðingu svöruðu. ${ }^{2-4,6,7,21}$ Bent hefur verið á að aldursbilið 6-24 mánaða er verulega viðkvæmt hvað varðar taugaproska barna, og stofnanavistun á pessum aldri hefur verið tengd við hættu á hegðunarvanda hjá sumum börnum. ${ }^{1}$ Pessu til viðbótar hefur verið sýnt fram á aukna tíðni hegðunarvanda á unglingsárum hjá börnum sem hafa í frumbernsku dvalið á stofnun. ${ }^{1}$ Líklega tengist pað meðal annars skorti á peim möguleika að mynda náin tengsl við umönnunaraðila á viðkvæmu aldursskeiði, sem er barninu eðlislægt. ${ }^{22}$ Tengslamyndun við umönnunaraðila er ekki aðeins grundvöllur að öryggi barnsins heldur einnig forsenda eðlilegs proska taugakerfisins. Einnig hefur hún áhrif á getu til að mynda heilbrigð geðtengsl síðar á lífsleiðinni. ${ }^{23}$ Pannig er örvun og umhyggja á viðkvæmu aldursskeiði nauðsynleg eins og bent hefur verið á í tengslakenningu John Bowlby. ${ }^{22}$

Pessi rannsókn er með lýsandi rannsóknarsniði og pví erfitt að fullyrða um beint orsakasamhengi. Hún byggir á svörum foreldra á ákveðnum matskvörðum en ekki á eiginlegri skoðun á börnunum sjálfum. Í pessum niðurstöðum er ekki litið til áhættupátta eins og ættarsögu um geðraskanir, meðgöngu og fæðingarsögu eða annarra sjúkdóma sem kunna að hrjá börnin. •að er pví erfitt að meta hvaða áhrif peir áhættupættir gætu mögulega haft. Pá er aðeins fyrir hendi almenn vitneskja um aðbúnað á mismunandi stofnunum innan og milli ættleiðingalanda og lítið vitað um bein áhrif á börnin. Petta eru pættir sem augljóslega gætu hafa spilað inn í geðslag og hegðunarmynstur barnanna. Einnig ber að hafa í huga að svör foreldra sem lúta að vanrækslu fyrir ættleiðingu eru ekki studd af eða staðfest með klínískri skoðun sérfræðinga. Upplýsingar um stofnanavistun eða vanrækslu fyrir ættleiðingu eru eingöngu settar fram af foreldrum. Рað mat foreldra að börnin hafi sætt alvarlegri vænrækslu fyrir ættleiðingu gæti vel markast af al- varleika hegðunarvanda barnanna. Pannig gæti petta frekar verið mat á áliti foreldra á orsök vandans en að parna sé um eiginlegt orsakasamband að ræða. Petta er í raun helsta takmörkun pessarar rannsóknar. Eigi að síður kusum við að greina frá pessu par sem niðurstöður gáfu ákveðna vísbendingu um samband parna á milli.

Svörunarhlutfall í rannsókninni, sem var tæplega 50\%, kann einnig að takmarka gildi niðurstaðnanna. Ástæða fyrir pessu svarhlutfalli er ekki ljós en ef til vill hefur lengd spurningalistanna haft eitthvað að segja. Helsti kostur rannsóknarinnar er hins vegar að pýðið er úr hópi allra ættleiddra barna en ekki úr tilvísanahópi, til dæmis hópi barna sem hefur verið vísað til skoðunar vegna hegðunar- eða geðvanda. Niðurstöðurnar ættu pví að gefa vissa heildarmynd af almennri stöðu hjá pessum hópi.

CBCL-hegðunarmatskvarðinn er mikið notaður í rannsóknum bæði vestan og austan hafs. Kvarðinn er staðlaður við bandarísk viðmið. Hins vegar verður að hafa í huga að mat foreldra á hegðunarfrávikum eru ekki alveg sambærileg milli pjóða. Petta parf að hafa í huga við túlkun niðurstaðna.

Í heild sýna pessar niðurstöður að pó flestum ættleiddum börnum erlendis frá farnist vel er skor pessara barna á matskvörðum um hegðunar- og tilfinningaerfiðleika hærra en í almennu pýði. Petta er í samræmi við erlendar rannsóknir á samskonar viðfangsefni. ${ }^{1,5,7,8}$

Meðalaldur barnanna pegar listarnir voru lagðir fyrir foreldrana var tæplega 7 ár og rannsóknarhópurinn pví tiltölulega ungur. Áhugavert væri að fylgja hópnum frekar eftir á komandi árum með tilliti til hegðunar og líðanar barnanna. Erlendar rannsóknir hafa bent til aukins hegðunarvanda pegar kemur að unglingsárum hjá peim börnum sem hafa dvalið á stofnun í frumbernsku. Par hefur verið litið á snemmskaðann af stofnanavistuninni sem orsakavald.

Lengd stofnanadvalar fyrir ættleiðingu skiptir máli í próun hegðunar- og tilfinningavanda barna. Til að takmarka stofnanaskaða ber að leggja áherslu á að börnin komist sem fyrst til kjörforeldra sinna. Samkvæmt pví sem fram kom í pessari rannsókn virðist skipta máli að ættleiðing eigi sér stað fyrir 18 mánaða aldur. Rutter og félagar rannsökuðu áhrif stofnanavistar á 111 börn ættleidd til Bretlands frá Rúmeníu fyrir tveggja ára, aldur samanborið við innlend ættleidd börn sem höfðu verið ættleidd fyrir 6 mánaða aldur. Peir skoðuðu pau fjögurra ára og 6 ára gömul og í ljós kom að ef börnin voru ættleidd fyrir 6 mánaða aldur náðu pau að fullu sambærilegum vitsmuna- og líkamsproska fjögurra ára gömul og jafnaldrar ættleiddir innanlands. Ef pau voru ættleidd eftir 6 mánaða aldur skoruðu pau marktækt hærra á hegðunarmatslistum 6 og 11 ára gömul en pau sem voru ættleidd fyrir 6 mánaða aldur. ${ }^{6}$ Erlendis hefur verið lögð áhersla á mikilvægi fræðslu, bæði til verðandi kjörforeldra og heilbrigðisstarfsfólks, um áhættu á tilfinninga- og hegðunarvanda ættleiddra barna. Snemmtæk íhlutun er mikilvæg til að bregðast rétt við hegðunar- og tilfinningaerfiðleikum barna. ${ }^{3,4}$ Mikilvægt er að vera vakandi fyrir pessum vanda og pekkja einkennin til að hægt sé að grípa inn í og hjálpa börnunum og fjölskyldum peirra.

Einkenni geta til að mynda lýst sér í erfiðleikum við myndun geðtengsla, ofvirkni- og einhverfulíkum einkennum, sértækum námserfiðleikum og lítilli félagshæfni, svo dæmi séu nefnd., 6 
Pau börn sem stríða við vanda af pessum toga purfa oft víðtæka pjónustu, heilbrigðis-, félags- og menntakerfis og góð samvinna er nauðsynleg til að sem best sé hægt að mæta pörfum peirra.

Niðurstöður pessarar rannsóknar eru að börn ættleidd erlendis frá eru líklegri til að sýna einkenni geð- og hegðunarvanda en börn úr almennu viðmiðunarbýði. Hærri aldur við ættleiðingu sem og dvöl á stofnun áður en börnin koma til kjörforelda virðast vera áhættupættir. Mikilvægt er að kjörforeldrar sem og aðrir sem umgangast ættleidd börn séu upplýstir um petta, pví íhlutun snemma gæti bætt stöðu barnanna.

\section{Heimildir}

1. Hawk B, McCall RB. CBCL behavior problems of post-institutionalized international adoptees. Clin Child Fam Psychol Rev 2010;13: 199-211.

2. Rutter M, Andersen-Wood L, Beckett C, Bredenkamp D, Castle J, Groothues C, et al. Quasi-autistic patterns following severe early global privation. English and Romanian Adoptees (ERA) Study Team. J Child Psychol Psychiatry 1999; 40: 537-49.

3. Zeanah CH, Keyes A, Settles L. Attachment relationship experiences and childhood psychopathology. Ann N Y Acad Sci 2003; 1008: 22-30.

4. Zeanah $\mathrm{CH}$, Smyke AT, Koga SF, Carlson E; Bucharest Early Intervention Project Core Group. Attachment in institutionalized and community children in Romania. Child Dev 2005; 76: 1015-28.

5. Casat CD, Norton HJ, Boyle-Whitesel M. Identification of elementary school children at risk for disruptive behavioral disturbance: validation of a combined screening method. J Am Acad Child Adolesc Psychiatry 1999; 38: 1246-53.

6. Rutter M, Kreppner J, Croft C, Murin M, Colvert E, Beckett C, et al. Early adolescent outcomes of institutionally deprived and non deprived adoptees. III Quasi-autism. J Child Psychol Psychiatry 2007;48: 1200-7.

7. Rutter M, Beckett C, Castle J, Colvert E, Kreppner J, Metha $\mathrm{M}$, et al. Effects of profound early institutional deprivation: An overview of findings from a UK longitudinal study of Romanian adoptees. Eur J Dev Psychol 2007; 4: 332-3-5.

8. Johnson D. How are the children doing? International adoption project. University of Minnesota 2001.
9. Goodman R. The extended version of the Strenghts and Difficulties Questionnaire as a guide to child psychiatric caseness and consequent burden. J Child Psychol Psychiatry 1999; 40: 791-801.

10. Hrafnsdóttir AH. Athugun á próffræðilegum eiginleikum Spurninga um styrk og vanda í hópi 5 ára barna á Íslandi. Sálfræðiritið 2006; 10: 71-81.

11. Skarphéðinsson G, Magnússon P. Spurningar um styrk og vanda (Strenght and Difficulties Questionnaire) Íslensk handbók. Barna- og unglingageðdeild Landspítala, Reykjavík 2005.

12. DuPaul GJ. ADHD Rating Scale - IV: Checklist, norms and clinical interpretation. Guildford Press, New York, NY 1998.

13. DuPaul GJ, Anastropoulos AD, Power TJ, Reid R, Ikeda MJ, McGoey M. Parent ratings of attention- deficit/ hyperactivity disorder: Factor structure, normative data and psychometric properties. J Psychopathol Behav Assmt 1998; 20: 83-102.

14. Skarphéðinsson G. Ofvirknikvarðinn (Attention - deficit hyperactivity disorder rating scale IV). Handbók, óutgefin 2008.

15. Magnusson P, Smari J, Gretarsdottir H, Thrandardottir $\mathrm{H}$. Attention-deficit/hyperactivity symtoms in Icelandic schoolchildren: Assessment with the attention-deficit /-hyperactivity rating scale-IV. Scand J Psychol 1999; 40: 301-6.

16. Ehlers S, Gillberg C, Wing L.A screening questionnaire for Asperger syndrome and other high-functioning autism spectrum disorders in school age children. J Autism Dev Disord 1999; 29: 129-41.
17. Skarphéðinsson G. Skimunarlisti einhverfurófs (Austism spectrum screening questionnaire), Handbók, útgáfa 1.1. Landspítali, Reykjavík 2008.

18. Achenbach TM, Rescorla LA. Manual for the ASEBA school-age forms and profiles. University of Vermont, Research Center for Children; Youth and Families, Burlington VT, 2001.

19. Achenbach TM, Rescorla LA. Manual for the ASEBA preschool forms and profiles. University of Vermont Research Center for Children; Youth and Families, Burlington VT, 2000.

20. Drotar D, Stein REK, Perrin EC. Methodological issues in using Child behavior checklist and its related instruments in clinical child psychology research. J Clin Child Psychol 1995; 24: 184-92.

21. Smyke AT, Koga SF, Johnson DE, Fox NA, Marshall PJ, Nelson CA, et al. The caregiving context in institution reared and family reared infants and toddlers in Romania. J Child Psychol Psychiatry 2007; 48: 210-8.

22. Bowlby J. Attachment and loss. Vol. 1 Attachment. Basic Books, New York, NY 2000.

23. Ziegler D. Traumatic experience and the brain. A handbook for understanding and treating those traumatized as children. Acacia Publishing, Inc. Phoenix, Arizona 2002.

\section{ENGLISH SUMMARY}

\section{Relationskip between pre-adoptive risk factors and psychopathological difficulties of internationally adopted children in Iceland}

Lorange $\mathrm{M}^{1}$, Kristmundsdottir $\mathrm{K}^{1}$, Skarphedinsson $\mathrm{G}^{1}$, Hermannsdottir BS ${ }^{2}$, Oddsdottir LB², Sigurdardottir DB ${ }^{1}$

Objective: In recent years a number of children have been adopted to Iceland. The aim of our study was to evaluate which factors may affect their mental and behavioural health.

Materials and methods: Information was collected on the health of internationally adopted children in Iceland as well as on pre-adoptive risk factors. This was done using a survey developed by Dr. Dana Johnson from the International Adoption Project at the University of Minnesota in the United States. Other questionnaires include the Child Behavior Checklist (CBCL), Strenghts and Difficulties Questionnaires (SDQ), Attention Deficit/Hyper activity Rating Scale (ADHD-RS-IV) and Austism Spectrum Screening Questionaire (ASSQ). For the comparative analysis data from the general population was used.
Results: Children adopted after 18 months of age and who have been institutionalised for 18 months or more showed higher risk for ADHD symptoms and behavioral and emotional problems than the general population. In addition, those who were subject to severe emotional neglect had significantly higher scores on CBCL, SDQ and ADHD-RS. A trend was seen between risk factors and scores on ASSQ. Children adopted before 12 months of age scored within the normal range on all questionnaires.

Conclusion: These results suggest that children adopted after 18 months of age are at risk of psychopathological difficulties. These results emphasize the importance of early adoption and of minimizing the time spent in an institution.

Key words: adoption, institution, neglect, behavioral and emotional problems. Correspondence: Dagbjorg B. Sigurdardottir, dagbjorg@landspitali.is 